\title{
Fashion Orientation among Muslim Female Students (Santriwati)
}

\author{
Farida $^{1}$, M. Nazaruddin ${ }^{2, *}$ \\ ${ }^{1,2}$ Faculty of Social and Political Sciences, Universitas Malikussaleh, Muara satu, 24355 Kota Lhokseumawe, Aceh, Indonesia \\ *Corresponding author e-mail address: adiraffareeda@gmail.com
}

\begin{abstract}
This study examines the orientation of fashion products consumed by students of the Al-Hanafiah Foundation Putri Muslimat Islamic Boarding School. This study examines the orientation of fashion products consumed by Muslim female students (santriwati). Researchers use qualitative research methods in collecting and analyzing data. Researchers also use the perspective of postmodern studies in the view of Jean P. Audillard and other postmodern figures as research instruments in conducting research approaches. Data analysis techniques used in this study refer to the interactive analysis method using data reduction, data presentation, concluding, and data verification. The results showed that the fashion consumed by Muslim female students at the Al-Hanafiah Foundation Putri Muslimat Islamic Boarding School is oriented to beauty, confidence, prestige, self-image, identity, and oriented as group cohesiveness.
\end{abstract}

Keywords: orientation, fashion, female students (santriwati), Muslims, consumption.

\section{Introduction}

Since Aceh was established as a province that implements the Islamic Sharia Qanun, the view of veiled women has become familiar in every place such as schools, banks, government buildings, and offices. All Muslim women are required to wear a veil. In the 1980s, most of the women who wear headscarves were only those who studied in Islamic boarding schools and those who attended special schools that taught Islam or those who had graduated from there (Ali, 2012).

Factors underlying the lack of desire of Muslim women to wear the veil at that time because of a government ban that does not allow women to wear the veil in public schools, colleges, and offices. On March 17, 1982, the Ministry of Education and Culture (Ministry of P and K) of the Republic of Indonesia issued Decree (SK): 052/C/Kep/D/82, which regulates the shape and use of school uniforms in state schools and state tertiary institutions. The government associates veil users in schools and colleges as political movements that want to oppose the government regime (Alatas, 2008).

Today, along with the lifting of the veil ban for Muslim women and in line with the stipulation of Islamic Sharia in Aceh Province, Muslim dress experiences various changes and advancements. The community even has various other names to represent the veil. Society no longer mentions the name of the veil, veil began to be called the hijab, pashmina and is now commonly known as the hijab. Muslim fashion trends and fashion are increasingly known to the wider community. Industries producing Muslim clothing are also increasing by bringing up the latest trends and fashion (Kurniawan, 2012).

Changes in fashion in the field of Muslim clothing seen with the emergence of robe clothing innovation. The robe that was once unpopular and considered to be classy clothing, is now a fashion 
trend, especially among mothers. The robe is also a trend among female students who are combined with special designs and modes for female students. Like the hoody robe, which is a long dress that has a coat hat that integrates with the shirt and can be extended to the head. Muslim fashion is increasingly becoming a fashion trend with the emergence of young Muslim designers who are making Muslim female students increasingly interested in consuming fashion (Toriq, 2012).

Based on this background, the researchers are interested in researching fashion orientation among Muslim female students of the Al-Hanafiah Foundation Putri Muslimat Islamic Boarding School.

\section{Literature Review}

\subsection{Consumption concept}

Storey (2006) argue that consumption means the use of commodities to satisfy needs and desires. Consumption does not only involve buying some goods, but also consuming services. Like going to places of entertainment and various social experiences. At present, the object of consumption can determine the prestige, status, and certain social symbols for the wearer. The object of consumption is also able to form differences at the level of signification. People tend to judge and recognize others by what they are wearing. Ranging from accessories, bags, shoes, glasses. The product is valued by brand and price because branded goods are represented as goods that have exclusivity value.

According to Baudrillard (2004), consumption is a systematic act of manipulating signs where objects are always manipulated in a broader sense as signs that distinguish individuals and groups. Thus the object consumed must have a sign or be a sign. Therefore people tend to consume goods that have more value than those owned by others. When we consume an object, internally people deconstruct the sign behind the object. That is the reason why we choose clothes that are of this or that model, bags of this or that model, and so on. That is because what we want to buy is not just the clothes or bags, but also the popular value, the value of glamor, or the value attached to the object.

Consumption behavior blurs one's class and social status. Humans are no longer consuming because to meet their needs, but more likely to fulfill their desires. When the production of capitalism reaches the peak of the abundance of goods and the needs of goods produced are fulfilled, companies no longer only create goods, but at the same time create needs. This is an effort of market capitalism to continue to dominate life. Capitalism utilizes the engine of desire to continually shackle society in the snare of consumerism through a variety of instinctive and persistent ways of persuasion (Baudrillard, 2004).

\subsection{Fashion concept}

Etymologically, fashion is related to Latin, which is factio, which means to make. The original meaning of fashion is an activity carried out by someone. The meaning of fashion also refers to the disclosure that forms of fashion are the most specified commodity to be produced and consumed by a capitalist society. Therefore fashion is the most significant way to be used in constructing, experiencing, and understanding social relations at present (Hendariningrum, 2008).

Polhemus and Procter show that in contemporary western society, the term fashion is often used as a synonym for the terms of dress, style, and manner of dress. In the word dress as a verb is interpreted as self-dressing behavior by paying special attention. This means more than just dressing by presenting certain styles such as adding accessories and giving a touch of style to fashion to create a fashionable impression. However, not all styles will always look fashionable. Barnard said that when a style passes, then when the style is used again, the user can be said to be outdated, meaning that what he is wearing is no longer a fashion trend today (Syamrilaode, 2011).

Fashion is defined as a style that is accepted and used by the majority of members of a group at one particular time. The process of fashion formation influences all types of cultural phenomena such as clothing, art, and architecture. The existence of fashion can be considered as a code or language that helps understand the meanings of people who consume fashion. According to Solomon, fashion is a social-diffusion process in which a new style is adopted by a group of consumers. Fashion refers to a 
combination of several attributes imposed by consumers. The combination applied has been evaluated positively by a reference group. Then only someone or a group of consumers is said to be fashionable.

Aspects of fashion include style and design. Fashion affects style and design. A style can be accepted and can be released within a certain period. In terms of clothing, style is characteristic in representing something. In terms of clothing, style is the appearance characteristic of a clothing material that consists of features that distinguish it from clothing. The study of fashion is not just about clothes, but also the role and meaning of clothing in social action. In other words, fashion can be metaphorical as a social skin that carries the message and lifestyle of a particular community. Fashion is also a means of communication in expressing a certain identity of individuals who consume fashion products (Ritzer, 2007).

\subsection{Consumption Society Orientation}

According to Baudrillard, consumers are no longer driven by the needs and demands of consumers. But rather by the abundant production capacity. So that the problems that arise in the system of consumption society are no longer related to production, but rather to the contradiction between higher levels of productivity and the need to distribute products. Therefore, the vital key in the current system is to control the mechanism of production as well as consumer demand as part of planned socialization through codes (Baudrillard, 2004).

Baudrillard asserted that consumption patterns of consumption society were marked by the shift in consumption orientation which was originally intended for the needs of life to become a lifestyle. Their consumption is more oriented to the values of goods consumed. For example, now someone would prefer branded and expensive products to other similar products with the same efficiency at a low price. For Baudrillard, it shows how people are more fixated on the consumption of symbols compared to the use of goods (Baudrillard, 2004).

In a critical theory through one of the works entitled Baudrillard "America", Baudrillard offers a fatal strategy, he said consumption orientation is seen from the subject. The importance of seeing objects rather than subjects. How the presence of the object currently lies in the process of expectations is to get endless satisfaction. This fatal strategy explains the existence of tautology, fashion, terrorism, obesity, and hyper-reality. There is a seduction to form a self-image by becoming more beautiful than more beautiful. More evil than more evil, fatter than fatter, and more real than real (Utoyo, 2001).

In the current system of society, symbols and self-images increasingly defeat reality. Appearance is more important than essence. The image can change objects with the same function to be different. Image distinguishes one object that can be of high value compared to another. Citra also makes people willing to sacrifice more for consumption whose function is not significant. Society is influenced by communication media tools that offer a variety of products that consumers want. Because the system is a vital device in the construction of symbolic reality. The mass media plays a very significant role in transferring and spreading symbolic values to the community (Baudrillard, 2004).

\section{Research Methods}

\subsection{Research Object and Location}

This research was conducted at the Al-Hanafiah Foundation Putri Muslimat Islamic Boarding School, Gampong Putoh, Samalanga District. The reason for choosing the Al-Hanafiah Foundation Putri Muslimat Islamic Boarding School as a place of research is because there is a phenomenon of fashion consumption in the lives of female students. Like fashion consumption of clothing, cosmetics, accessories, and products supporting its appearance. Al-Hanafiah Foundation Putri Muslimat Islamic Boarding School or better known as the Al-Hanafiah Foundation Putri Muslimat Islamic Boarding School is a special dayah that receives girls' dayah. Based on the documentation data on the profile of the Al-Hanafiah Foundation Putri Muslimat Islamic Boarding School on July 20, 2012, it can be seen that the Al-Hanafiah Foundation Putri Muslimat Islamic Boarding School was established on September 20, 1975, by Tgk. H. Jalaluddin bin Tgk. H. Hanafiah. At present, the Al-Hanafiah Foundation Putri 
Muslimat Islamic Boarding School is under the leadership of Tgk. H. Ahmadallah. Al-Hanafiah Foundation Putri Muslimat Islamic Boarding School is engaged in the following fields.

1. Dayah education by studying the yellow book and the Arabic book.

2. Formal education which includes Junior High School (Mulimat Middle School), Senior High School (Muslimat High School).

3. Majlis ta'lim.

4. Dayah productive economic business.

The number of residents of the Al-Hanafiah Foundation Putri Muslimat Islamic Boarding School based on data taken from the documentation of the Al-Hanafiah Foundation Putri Muslimat Islamic Boarding School on July 20, 2012, can be seen in Table 1.

Table 1: Documentation of the Al-Hanafiah Foundation Putri Muslimat Islamic Boarding School

\begin{tabular}{lr}
\hline \multicolumn{1}{c}{ Boarding School Residents Group } & Number \\
\hline The teacher who stays at the location of the Islamic Boarding School & 115 people \\
PNS/GTT teacher & 53 people \\
Aneuk Dayah is a middle school female student & 425 people \\
Aneuk Dayah is a high school female student & 765 people \\
Aneuk Dayah is a college female student & 90 people \\
Aneuk Dayah Salafiah & 465 people \\
Total Overall Aneuk Dayah & 1.745 people \\
\hline
\end{tabular}

\subsection{Research methodology}

Researchers used qualitative research methods using a phenomenological approach in the form of case studies. Phenomenology is defined as a subjective experience of consciousness from one's main perspective. The purpose of phenomenology research is to explain what experiences a person experienced in this life, including his interactions with others (Moleong, 2010). The phenomenon that will be investigated by researchers is the phenomenon of fashion consumption among students of the AlHanafiah Foundation Putri Muslimat Islamic Boarding School. Here the researcher tries to understand the meaning of the event and its links to the people who are in the lives of the students of the AlHanafiah Foundation Putri Muslimat Islamic Boarding School, by the formulation of the problem to be examined in this study.

\subsubsection{Informants and Data Sources}

The informants are the students of the Al-Hanafiah Foundation Putri Muslimat Islamic Boarding School who often and always follow the development of trends and fashion. In this study, the informants were obtained by purposive sampling. The sample was chosen intentionally with an amount not determined at the beginning of the study. The first step is to determine who can provide key information. The first informant was asked to appoint someone else who could distinguish information. Then the informant is asked to show other people who have information and so on until reaching the level of redundancy, completeness, meaning that it is considered sufficient for the information needed (Saebani, 2008).

The process of obtaining informants at the study site was carried out by researchers by selecting a bedroom inhabited by senior female students. From the senior female students, researchers obtained information about female students who consumed fashion. Santriwati senior will tell her friends who are considered to consume a lot of fashion products and friends who are just starting to consume fashion. From one female student, the researcher obtained information in a snowball manner until it reached a stage that was sufficient for the desired data. Santriwati senior also became a research intermediary to interact and exchange opinions with dayah administrators.

This study uses three key informants who know the ins and outs of female students and have the wisdom in providing information so that the validity of the data can be trusted. The first key informant is Guru Atikah as the person appointed by the leader of the Dayah Putri Muslimat who has access to the information needed for research data. Second is Rizka Nadia as a senior female student who has now 
lived for six years at the Dayah Putri Muslimat, and she is also a teacher. Rizka also served as an intermediary bridge between the researchers and the Muslimah Dayah female management teachers. The third is Riski Fitria as a female student who has been living for three years at Dayah Putri Muslimat. Currently, Riskia is a third-grade student at Putri Muslimat High School. Riskia is a female student who is considered fashionable and has the influence of fashion on her friends.

There were seventy-one informants from female students, including the three key informants mentioned above. They consist of female students from various regions and different bedrooms between one another. Then there were informants from the teachers who were included in the board of the Muslim Women's Dayah. The teachers who are informants here are those who are substitute teachers, teachers who become homeroom teachers, and teachers who have more than 15 years of living in Dayah Putri Muslimat.

Sources of data in this study were obtained through two sources, namely sourced from data in the field of observation and in-depth interviews. To strengthen the data, researchers also used documents in the form of photographs of the activities of the Al-Hanafiah Foundation Putri Muslimat Islamic Boarding School related to consumption and fashion orientation among students of the Al-Hanafiah Foundation Putri Muslimat Islamic Boarding School. Sources of data in the field were research informants, namely female students of the Al-Hanafiah Foundation Putri Muslimat Islamic Boarding School.

\subsubsection{Data collection technique}

Data collection techniques used in this study are as follows.

Observation. Researchers use observation techniques (observations). The observation process was carried out in a participant-observation manner, in which the researcher was directly involved in the lives of the female students by participating in the activities of the female students of the Al-Hanafiah Foundation Putri Muslimat Islamic Boarding School in the surrounding environment and outside activities, such as when attending wedding parties and the like. Researchers carefully observe and examine all activities related to fashion consumption among students of the Al-Hanafiah Foundation Putri Muslimat Islamic Boarding School.

In-depth Interview. In-depth interviews are used to interview informants to obtain data and information about research problems. The interview process is carried out in person (face to face) with informants, questions, and answers conducted verbally to record the information needed by the objectives of the researcher.

Documentation. The documentation technique was carried out to perfect and strengthen the data. Documentation is done by tracing the notes. Both from the newspaper, references, and documenting photographs of students activities Al-Hanafiah Foundation Putri Muslimat Islamic Boarding School.

\subsubsection{Data analysis technique}

In the process of data analysis techniques, researchers used the instrument of Consuming Sociology and Postmodern Studies as a knife of analysis in dissecting matters relating to fashion consumption. Data collected in the field will be analyzed using an interactive model by the following steps.

Data reduction. Researchers make transcripts of all interviews in depth. Transcription was made to facilitate the process of mapping and categorizing data. Then researchers make data categorization to produce data grouping based on chapters that have been designed. Furthermore, researchers compare data intended to find less valid data.

Presentation of data. The presentation of data is done in the form of a brief description by describing the relationships between categories and the like. Researchers link and compare data obtained from indepth interviews. From observations, and data obtained from documentation to produce meaningful concepts.

Making Conclusions and Verification. Data that has been compared and then interpreted using descriptive methods. Interpretation is done by interpreting data in the form of describing and telling research. The results of data interpretation obtained from primary data (interviews and observations) and secondary data (books, mass media, internet, journals, and laws and regulations). To avoid 
misinterpretation of the data and the maturation of the results obtained, a reinterpretation of the conclusions is made (Saebani, 2008).

\section{Results dan Discussion}

\subsection{Products that Become Fashion in Santriwati of the Al-Hanafiah Foundation Putri Muslimat Islamic Boarding School}

Basic human needs consist of primary and secondary needs. But in modern times human needs are increasingly diverse. The level of needs that are increasingly diverse and continuously developing make students do a lot of consumption activities. Starting from the consumption of daily food, clothing, cosmetics, accessories, and even other appearance support tools. The consumption commodity that is the focus of this research is not a commodity of the type of food, but it leads to the consumption of clothing, cosmetics, and appearance support tools. Not all products consumed by female students become fashion products among female students. There are only a few products that are fashionable among Dayah Putri Muslimat students. Products that are fashionable among female students are divided into four categories: fashion, cosmetics, fashion accessories, and sandals, and shoes.

\subsubsection{Fashion Clothing}

As for the fashion trends that are developing in the consumption of clothing among female students are blouse (clothes made from cloth and long sleeves). There are several kinds of blouse modes that have been favored, including over-layer arm blouse, thousand buttoned blouses, flower sleeve blouse, and batik blouse. Furthermore, there is a couple of fashion trend that is a favorite dress lately. Couple clothes are a pair of T-shirts that have almost matching colors and are labeled with words for couples such as LO-VE, My Love is You or You Are My Love. Fashion clothing that is developing into a fashion trend among female students today is a dress, robe, and tunic.

Muslim female students always combine the clothes they wear with the hijab. Jilbab is one of the most important consumption commodities in the needs of female students. The hijab is a cloth covering the hair, head, neck, and chest. The hijab is always worn in daily activities and when Muslim female students leave the house. The headscarf that is fashionable among female students is the Paris headscarf, a kind of rectangular headscarf. Paris hijab is available in a variety of colors desired by female students so that it is easy to match the color of the clothes they wear. Based on observations, Paris headscarves developed fashion from time to time with various additions to modes and patterns. Like the embroidery patterns of threads and beads and ribbons in the hijab Paris.

Paris' hijab is created by fashions that are trending in society. So that the Paris hijab is not outdated until now. Then the hijab that became fashionable among female students was instant hijab, the readymade hijab, better known as the hijab brackets. The hijab that became the next fashion trend was Pashmina, most of the people of Indonesia called Pashmina as a shawl. The pashmina can be created with a variety of styles so that it is never outdated. Hijab fashion is created because of several things. First, there is a modification and innovation of a type of veils such as the Paris and pashmina headscarves. Second, fashion is formed because it has more value than other headscarves due to the brand attached to the headscarf even though the brand is not known by its original name. After all, the brand name is adapted to the dialect of the local community. Third, hijab fashion is formed based on the influence of Islamic religious films.

\subsubsection{Cosmetic Fashion}

Cosmetics are ingredients or preparations intended for use on the outside of the human body (epidermis, hair, nails, lips, and external genital organs) or teeth and oral mucosa, especially to cleanse, fragrance, change appearance and/or improve body odor or protect or maintain the body in good condition (Juliana, 2013). Cosmetic products used by the majority of female students are divided into categories of facial care, body care, and make-up tools. In the past, make-up was a shame if it was used for daily activities, especially for female students. The use of make-up is only intended for those who 
become brides or attend certain events. But now, make-up is a daily cosmetic that is used by female students and is not common anymore in the community.

\subsubsection{Fashion Accessories}

The use of accessories among Muslim students of the Al-Hanafiah Foundation Putri Muslimat Islamic Boarding School is part of fashion. Accessories have a period of fashion in every appearance. Consumption of accessories aims to beautify the appearance, unite together with friends, and to look different from friends. Some types of accessories that are often worn by Muslim students of the AlHanafiah Foundation Putri Muslimat Islamic Boarding School include brooches, such as hijab or tunic brooches, necklaces, rings, and watches.

\subsection{Fashion Orientation among Muslim Santriwati of the Al-Hanafiah Foundation Putri Muslimat Islamic Boarding School}

Baudrillard asserted that the consumption patterns of consumer societies are marked by the shift in consumption orientation which was originally intended for the necessities of life to become a lifestyle. Their consumption is no longer oriented to the necessities of life but rather the lifestyle as described above. For example, now someone would prefer branded products to other similar products that are equally effective and cheaper. For Baudrillard, it shows how people are more focused on the consumption of symbols rather than usefulness (Baudrillard, 2004). The following are the fashion orientations that exist among students of the Al-Hanafiah Foundation Putri Muslimat Islamic Boarding School.

\subsubsection{Beauty Orientation}

Beauty is understood by a variety of perceptions by everyone. The perception of beauty departs from the judgment of many people. The body is the object of forming individual evaluations of beauty, where the body is represented as beauty with various things attached to the body itself. Ideal beauty among students of the Al-Hanafiah Foundation Putri Muslimat Islamic Boarding School is assessed by having white and brightly colored skin, smooth face and the addition of appearance-supporting devices that support her beauty. The desire to look beautiful and considered beautiful makes the individual of the female student do various things to gain recognition of her beauty. Various beauty products are consumed such as using skin whitening cream on the face, using body lotion with frill whitening, using acne removal cream and face lightening, hair dyeing and rebounding.

Among female students, beauty is a support in their daily life to be liked by their friends or students. As Melati said (name obscured): The four of us have been close friends for 3 years. Often two of my friends feel uncomfortable walking with me and Mila (name disguised) because every time I meet with friends from other bilek or our students, I and Mila are pretty, sweet and they are not. Because they do not have bright skin and no zits (Interview, February 25, 2013).

Melati realized that praise and being liked by many friends was a form of her success in maintaining her beauty and appearance as a female student today. Melati realized that she was liked by friends because she was beautiful and as long as she maintained her beauty that praise would continue to be obtained. The same thing was also said by Siti: Good appearance and model (fashion) makes us fashionable. We look good, so we like lots of people and lots of friends (Interview, February 25, 2013).

Based on interviews with female students of the Al-Hanafiah Foundation Putri Muslimat Islamic Boarding School about fashion and beauty orientation among female students in Lhkoseumawe kora, the results are relevant to what was stated by Baudrillard in one of his works "Consumption Society" (Baudrillard, 2004). Baudrillard describes the beauty of women as an absolute condition, a religious condition. Beauty is no longer the influence of nature, nor is it a secondary moral quality, but a fundamental quality, mandatory from the nature of women who care for their faces and their slimness as their souls. Signs of election in the body are like success at work.

Furthermore, Baudrillard argues that the ethics of beauty are truly fashion ethics. This fashion ethic is formulated as a decrease of all concrete values, the "use value" of the body as an object of beauty with the only functional exchange rate summarized in the value itself. Beauty is nothing more than a set of 
exchanged signs. It functions as a sign value (Baudrillard, 2004). On observation, the way students of the Al-Hanafiah Foundation Putri Muslimat Islamic Boarding School present themselves in front of people is a sign that someone is still a child or an adult is when someone is very concerned about his appearance. Then the sign value obtained is maturity.

This happens to other female students, where female students try to care for their skin to get recognition from their smooth and white skin to increase confidence in their relationships. All cosmetics that are used aim to be exchanged with pride and praise from her friends and satisfaction because it has succeeded in adding beauty. As Rahma said: Everything I do to my body is for beauty. My hair smoothing is the main goal so that my hair is beautiful, secondly because it is fashion (Interview, March 12, 2013).

Beauty orientation in consuming fashion also includes aneuk dayah appearance, such as clothing, accessories and other appearance supporting devices. The thought of the importance of appearance, made the students of the Al-Hanafiah Foundation Putri Muslimat Islamic Boarding School try to look their best in front of people. As said by Riskia: The beautiful appearance that follows fashion, cool, not outdated, macthing between clothing, accessories and cosmetics. Because appearance is number one. The appearance of everything to appear in front of people (Interview, March 13, 2013).

A similar opinion was also expressed by July: Appearance is very important, people will see us from our appearance. So what we wear must be good when seen. Even though sometimes we use other people's loans. Just don't look ugly like wearing clothes like running clothesline, the colors don't match, it's tacky and can be a laughing (Interview, March 13, 2013).

From the above interview, it can be understood that appearance is very important in the daily lives of female students. A person's personality is internalized in his style of dress. The ideal style of dress is to follow the dress code that many people like, by displaying a matching color between the terms of clothing worn. Many ways are done to offer a beautiful appearance, such as work around this by borrowing friends' clothes and swapping clothes. Appearance in dressing and dressing shows another person's interpretation of the consumer's personality. Appearance affects the mindset and confidence of consumers to appear in front of others.

\subsubsection{Confidence Orientation}

Confidence is a mental or psychological condition of a person, where the individual can evaluate the whole of himself to give strong confidence in his ability to take action in achieving various goals in his life (Hariyanto, 2010). Self-confidence called the confident word among female students understands the condition free from the anxiety of other people's negative perceptions of themselves and the goods they consume (Observation, January to March 2013).

A person is considered fashionable when he or she always appears in a fashion that is in harmony, that is, the color of the headscarf is the same as clothes, the color of clothes is the same as a sarong. Even the accessories worn are also the same as clothing. As Viza said: It doesn't matter where our clothes don't match like wearing a red shirt but the sarong is orange, then the hijab is blue. It's tacky. But even if matching around dayah is not a problem (Interview, March 23, 2013).

Often the use of cosmetics to increase confidence in front of friends and students. A dull and spotty face can be a factor of discomfort (not confident) to appear in public. Cosmetic products that are used are no longer just a cosmetic tool that only cleanses the body. But more than that the use of cosmetics affects the concentration of individuals in interacting with others. There is anxiety and feelings of inferiority when others make unwanted comments about their pimply faces or when the female student's make-up is considered old-fashioned by her friends. The views and perceptions of others influence self-confidence, thereby creating the need for fashion consumption.

The students of the Al-Hanafiah Foundation Putri Muslimat Islamic Boarding School also have a sensitivity to what is currently popular or in other words called trends. Santriwati of the Al-Hanafiah Foundation Putri Muslimat Islamic Boarding School tends to follow the fashion that is popular among her friends. Accessories combined with clothing worn, initially according to desire, eventually became like a necessity. Confidently hanging out with friends when the accessories owned are accessories that are becoming a trend. Interested in new models and to get social recognition. They feel less sociable if 
they do not have accessories that are being used by many people, finally decided to buy the same accessories with their friends.

Fear of lagging behind the development of fashion makes students try to buy interesting items and follow fashion that is in force because if not they will be considered old school (antiquity). In fashion, every individual feels the need to renew himself every year, every month, or every season, through new items that he buys. If this is not done, there is a sense of worry left behind from fashion trends, there is a sense of insecurity using something that is considered old school (Observation, January to March 2013).

This kind of thing is not a form of progress, because fashion is always changing, changing, rotating, and not adding anything to the value of an individual. as Baudrillard said, fashion controls young people today as resistance to any form of a command, resistance without ideology (Ritzer, 2007), where individuals must wear clothing that is considered matching in the eyes of the general public without resistance. Matching is likened to a code that justifies that a good appearance is a matching one. So that when individuals do not look like the code commands, then the consequence is to be a laughing stock at others and affect their confidence. Likewise with the use of cosmetics and hair fashion. The code seems to convey, if you want to be confident, then use quality cosmetics, trending accessories, and haircuts with the latest fashions.

\subsubsection{Group Orientation and Group Identity}

One way for female students to show their group identity is by wearing the same fashion. The same fashion makes them more confident in showing the cohesiveness and identity of their group. The more fashionable the members of a group. Then it is considered as classy as their group. The group in the aneuk dayah group is the friendship group. The group is formed from the familiarity and togetherness of the class (school) and becomes in everyday life. The group also has names derived from the names of group members namely RIFN, RICUERA, NAFA, LIBIDIH, AGAS, TITARINIRA, DIMI3, UZFIFAYA, and many others. Groups often use the same thing as group members. Wearing the same sandals, clothes, sarong, and accessories. Sometimes it's not just the same item shape, but the color too. Some opinions about the group as spoken by Mila: Previously, there was a famous group, the three of them, everywhere there were always three of them if you wear clothes always the same, sandals and accessories are the same, the shape, the color is the same (Interview, January 30, 2013).

According to Titta M. Habibi, cohesiveness is togetherness in an activity or thought to achieve a goal. Cohesiveness is the result of the process of uniting the vision and mission of all members in a group in achieving its goals. The compact is very closely related to a certain group. Each group has a goal to be achieved. So the compact will occur if the group cooperates with each other and find it difficult to struggle to achieve the group's goals (Firdaus and Munif, 2012).

In consumption, tastes, preferences, lifestyle, and value standards are determined by a superior class. The upper class not only excels politically economically but also culture by determining and doing hegemony in consumption patterns. Thus, we can categorize people through the tastes they manifest. For example, their preference for different types of music or film. This behavior, as well as all other behaviors, needs to be seen in the context of the overall reciprocal relationship. Thus, the special taste in art or film is closely related to the preference for food, sports, and fashion (Ritzer, 2007).

\subsubsection{Self-Image Orientation}

What is consumed by female students of the Al-Hanafiah Foundation Putri Muslimat Islamic Boarding School reflects who they are. Appearance is one of the basic needs and becomes a serious problem in trying to maintain the dignity of each individual. From observations made by the author, some female students hid from their friends when they were wearing something that was considered shameful and dropped their authority. Like when they leave the house to shop using only pajamas and headscarves that do not have the same color as the clothes they wear and faces that have no makeup whatsoever (Observation, February 2020).

Baudrillard (2004) said that in a consumer society, consumption as a system of meaning is no longer governed by the factor of need or desire to get pleasure, but by a set of desires for honor, prestige, status, and identity through a marking mechanism. To maintain self-image in the presence of others. Santriwati 
of the Al-Hanafiah Foundation Putri Muslimat Islamic Boarding School governs how to dress and dress someone in appearance, which is then used as a form to enhance their aesthetic value. But the results of the study show that there is another side to the different meanings of consumption explained by Baudrillard, namely self-image. A sociologist from France, Pierre Bourdieu connects consumption with symbols in society. According to Pierre, the product consumed is a symbol of one's status and social class. Consumption is formed by ideas, symbols, and tastes which then can indirectly create differences in society (Storey, 2006).

Based on observations made by the writer, there are incidents where there are some female students who consume fashion to be identified by others. As Dea said (name obscured): I must always look fashionable so my friends don't consider me a village person or a person from the interior (Interview, February 14, 2020). From Dea's words, it is clearly seen that the consumption carried out by female students' aims to be identified by others. The behavior of female students trying to look matching which is considered as an ideal appearance among female students themselves is not only limited to looking fashionable. However, he is communicating his social status through the consumption of fashion that he does. There is pride when what is worn can explain who he is and where he came from.

A person's social status will also be clearly seen when they wear clothes or something of a certain brand. There is a tendency to consider a child of the rich and the child of the poor from the goods he consumes. The brand of a particular product is a code or mark of one's identity. Piliang (1998) says that codes are a way of combining socially agreed-upon signs, to allow one message to be conveyed from one person to another. In the world of simulation, a person's identity, for example, is no longer determined by and from within himself. Identity is now more determined by the construction of signs, images, and codes that form a mirror of how an individual understands themselves and their relationships with others.

\subsubsection{Worship Orientation}

From observations in the field carried out by the author, when the students conduct worship together. Like praying in congregation, it is seen the teenagers wear prayer equipment such as mukenah (for Muslim women). Mukenah is used by Muslim students of the Al-Hanafiah Foundation Putri Muslimat Islamic Boarding School consisting of various fashions, various embroidery patterns in various colors, according to the development of today's fashion. When there are female students who wear the prayer with the latest fashions, their friends will ask questions about the prayer. Starting from the fabric, the price, and even the place of sewing. Beautiful fashion trends embroidery in this case besides the following fashion is also related to worship as Ria said: Thank God fashion now actually helps us in closing the genitals, like ciput ya, on one side of this ciput is a combination of headscarves, but on the one hand it is useful to cover our hair so that not coming out of the veil (Interview, 14 February 2013).

Understanding of religious advice to maintain cleanliness and neatness combined with its application in fashion. As Shinta said (name disguised): When we look good, just participate modestly so that the headscarves are neat, clothes are matching, the powder is not apron, our appearance is neat, not disheveled, can be the intention to worship. A similar opinion was also conveyed by Viza: If my clothes are not too involved in fashion, but if I want to wear a headscarf, it is not bad to take part in fashion, because this is to cover the nakedness, for worship. Cook in front of our people to look good, before God must also (Interview, February 14, 2013).

Based on the data above it can be understood that not all fashion productions are aimed at beautifying the appearance in front of people. But it is also internalized as an effort to worship God. The students of the Al-Hanafiah Foundation Putri Muslimat Islamic Boarding School understand Muslim clothing as Islamic clothing. Their Islamic identity and wearing it are worship, not just fashion trends.

\section{Conclussion}

Based on the results of previous studies, it can be concluded that the behavior of fashion consumption among female students of the Al-Hanafiah Foundation Putri Muslimat Islamic Boarding School has several interrelated orientations between one another. First, beauty-oriented fashion consumption among female students is understood appearance and make-up which is considered ideal by the general public. 
The desire to look beautiful and considered beautiful makes the individual of the female student do various things to gain recognition of her beauty and show a beautiful appearance. Among them by looking matching and up to date or not outdated. The desire to look beautiful makes students consume about fashion products. The lending and borrowing behavior of friends is a common phenomenon among female students.

Second, self-confidence orientation. The orientation of confidence is formed from the internalization of beauty orientation. The orientation of self-confidence among female students is understood by following the fashion trends in female students. There is a feeling of inferiority and worry when his appearance is not matched. Vice versa will grow self-confidence when what is displayed is considered good and follows fashion by his friends.

Third, prestige orientation. The prestige orientation among female students is understood as the result of following trends, using branded goods, be it cosmetics or headscarves, and following the development of fashion. The existence of prestige makes students confident in showing their existence. Like the estyle headscarf that became a luxury headscarf among female students and raised the prestige of female students who wore it.

Fourth, compactness orientation. Cohesiveness among female students is internalized in using uniforms. Every local recitation has uniforms that are worn when there are holidays and events inside or outside the dayah. Local uniforms are becoming a fashion trend among female students. Each local tried to show the best fashion from the locals. So that the local uniform which was originally aimed at cohesiveness becomes a competition in appearance and fashion. Fifth, image orientation. Self-image is understood as what is consumed by female students reflects who they are. All things about appearance become one of the basic needs and become a serious problem in seeking to maintain the dignity of each individual. In the understanding of female students, appearance becomes a matter that must be considered and guarded in public which is understood as maintaining self-image. A santriwati slang maintaining her self-image in front of others is interpreted as a necessity that must be done for herself and maintaining her self-image in front of others.

Sixth, identity orientation. Identity orientation among female students is understood as the way female students communicate and show their social status identity to others by what they consume, whether it is the style, products of a particular brand, and fashion among female students. There are two forms of identity orientation among female students. First, orientation to show his own identity as a child of poor people or poor people with fashion products he consumes. Second, orientation to show her identity as a female student. Fashion is adopted and adapted to the style of dressed students who wear long veils that cover the chest and loose clothes.

Seventh, worship orientation. Fashion oriented to worship among female students is understood as a way for female students to interpret their Islam by consuming modest fashion and in things that support worship in the form of Islamic fashion with embroidered fashions and motifs, ciput fashion used in addition to following current trends but prioritizing to prevent hair protruding from the veil, and fashion Muslim clothing that meets the criteria for ethical dress in Islam.

\section{References}

Alatas, A. (2008). Kasus Jilbab di Sekolah-Sekolah Negeri Di Indonesia Tahun 1982-1991. http://maaini.wordpress.com, accessed on January 24, 2020, 21:08 WIB.

Ali, K. (2012) Membincang Evolusi Jilbab di Indonesia: Khasanah. http://www.rahima.or.id, accessed on January 24, 2020, 18:20 WIB.

Baudrillard, J. P. (2004). Masyarakat Konsumsi. Yoyakarta: Kreasi Wacana.

Departemen Dalam Negeri Republik Indonesia. Qanun Provinsi Nanggroe Aceh Darussalam Nomor 10 Tahun 2002 Tentang Peradilan Syariat Islam. 
Firdaus, S. A. K. \& Munif, M. (2012). Makna Dari Sebuah Kekompakan. http://www.uin-malang.ac.id, accessed on March 1, 2013, 23.04 WIB.

Hendariningrum, R. (2008), Fashion dan Gaya Hidup: Identitas dan Komunikasi. Lease correct this Jakarta: Veteran..

Kurniawan, F. (2012). Busana Muslim Selebriti, dari Kaftan Syahrini Hingga Gamis Ashanty. http://hot.detik.com, accessed on February 16, 2020, 07:05 WIB.

Moleong, J. L. (2010). Metodologi Penelitian Kualitatif. Bandung: Santriwati Rosdakarya.

Piliang, Y. A. (1998). Sebuah Dunia Yang Dilipat: Realitas Kebudayaan Menjelang Milenium Ketiga dan Matinya Postmodernisme. Bandung: Mizan.

Ritzer, G. (2007). Teori Sosiologi Modern. Yogjakarta: Kreasi Wacana.

Saebani, A. B. (2008). Metode Penelitian. Bandung: Pustaka Setia.

Storey, J. (2006). Cultural Studies dan Kajian Budaya Pop. Bandung: Jalasutra.

Syamrilaode. (2011). Definisi Fashion Menurut Para Ahli. http://www. id.shvoong.com, accessed on February 19, 2020, 11:23 WIB.

Toriq. (2012). Arah Kebangkitan Muslimah. accessed on February 14, 2020, 22:27 WIB.

Utoyo, B. (2001). Perkembangan Pemikiran Jean P. Baudrillard: Dari Realitas ke Simulakrum. http://www.utoyoart.blogspot.com, accessed on February 12, 2020, 16:42 WIB. 